\title{
Polymerase Chain Reaction Amplification of Genomic Fragments of Bovine Herpesvirus-1
}

\author{
AL Cândido, ED Bontempo, M Resende ${ }^{+}$
}

Laboratório de Virologia Comparada, Departamento de Microbiologia, Instituto de Ciências Biológicas, Universidade Federal de Minas Gerais, Av. Antônio Carlos 6627, 30161-970 Belo Horizonte, MG, Brasil

Especial conditions were developed for the amplification of five DNA segments from US region of $B H V-1$ by polymerase chain reaction. In order to eliminate most nonspecific products it was found that addition of three cosolvents DMSO, glycerol and NP 40 was a simple method for increasing the specificity of amplification.

Key words: bovine herpesvirus-1 - cosolvents - polymerase chain reaction

Bovine herpesvirus-1 (BHV-1), commonly known as infectious bovine rhinotracheitis virus, is a prominent cause of disease in cattle (Gibbs et al. 1977). In Brazil, over 50 millions of animals may be infected (Lovato et al. 1995, Vidor et al. 1995). Virus isolation in tissue culture is the used method for detection of BHV-1 in clinical samples or semen but the principal drawback of the method is the length of time required to obtain results. Depending on the number of blind passages in tissue culture, the procedure may take one to three weeks to be completed. To overcome these difficulties attention has been directed toward the polymerase chain reaction (PCR) assays but major problems in the amplification of DNA from certain herpesvirus may arise due probably to their GC rich genomes. The BHV-1 genome is more than $70 \%$ GC rich (Leung-Tack et al. 1994).

We have developed PCR conditions allowing the efficient amplification of five DNA segments from US region of BHV-1 with primers designed on the published sequences of Leung-Tack et al. (1994) (Table). The nucleotide sequence data used in this paper are deposited under Genebank acession number Z23068. The optimization used the logical system of changes in $\mathrm{pH}$, magnesium, potassium chloride and annealing temperatures (Payne et al. 1995). We found that specificity was

This work was supported by PADCT II, CNPq and Fapemig.

${ }^{+}$Corresponding author. Fax: +55-31-499.2733.

E-mail: mresende@mono.icb.ufmg.br

Received 15 June 1999

Accepted 26 November 1999 difficult to achieve under these conditions for all five fragments with high GC contents. The reaction conditions were $2.5 \mathrm{mM} \mathrm{MgCl}_{2}, 50 \mathrm{mM} \mathrm{KCl}$, $10 \mathrm{mM}$ Tris-Cl pH 8.3, $0.2 \mathrm{mM}$ dNTP, $2.5 \mathrm{U}$ Taq polymerase in a final volume of $100 \mu$ overlaid with $50 \mu \mathrm{l}$ of silicone oil. All amplifications were performed in a MJ Research Minicycle. For amplifications the hot start protocol was featured when the samples were first heated at $95^{\circ} \mathrm{C}$ for $10 \mathrm{~min}$ to completely denature the template. After the denaturation, at $80^{\circ} \mathrm{C}$, the enzyme was added to each reaction beneath the layer of oil. The denaturation, annealing and extension temperatures and times were $94^{\circ} \mathrm{C}(30 \mathrm{sec}), 52^{\circ} \mathrm{C}(1 \mathrm{~min}), 72^{\circ} \mathrm{C}(1 \mathrm{~min})$ respectively for 35 cycles. The amplification was followed by a final elongation step of $10 \mathrm{~min}$. It was found that the parameters for denaturation, annealing and extension must be worked carefully. The reaction products were analyzed by agarose 2\% (Seakem ${ }^{\circledR}$ Gold Agarose, FMC) gel electrophoresis after ethidium bromide staining.

In order to eliminate most nonspecific products and increase the efficiency of the amplification the effect of the addition of several cosolvents such as formamide, DMSO, glycerol, NP40, tetramethylammonium chloride (TMAC) and replacement of $70 \%$ of dGTP by de ${ }^{7}$ GTP to the reaction was verified. It was found that the success rate of the amplification of the five GC-rich BHV-1 ORFs was significantly higher with the addition of $1 \%$ DMSO, $5 \%$ glycerol and $0.1 \%$ NP40 (Figure). The denaturant formamide, TMAC, replacement of dGTP by de ${ }^{7}$ GTP did not give the desired specificity.

In conclusion, the addition of the three cosolvents DMSO, glycerol and NP40 was found to be a simple and successful method for increasing the specificity of selected fragments of the BHV-1 genome. 


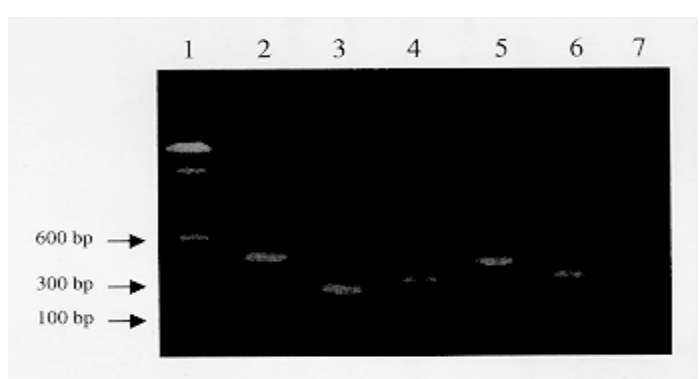

Specificity of amplifications of the BH-83 Brazilian strain with the addition of cosolvents DMSO, glycerol and NP40. Lane 1: 100 bp DNA ladder. Lane 2: fragment of $456 \mathrm{bp}$ (ORF 1). Lane 3: fragment of $267 \mathrm{bp}$ (ORF 2). Lane 4: fragment of $303 \mathrm{bp}$ (ORF 3). Lane 5: fragment of 411 bp (ORF 4). Lane 6: fragment of 352 bp (ORF 7). Lane 7: SHV-1 strain LA 031 (negative control).

\section{ACKNOWLEDGEMENTS}

To Marília Nadir dos Santos and Tânia Mara Gomes de Pinho for excellent technical support.

\section{REFERENCES}

Gibbs EPJ, Rweyemamu, MM 1977. Bovine herpesvirus I. Vet Bull 47: 317-343.

Leung-Tack P, Audonnet JC, Riviere M 1994. The complete DNA sequence and the genetic organization of the short unique region (Us) of the bovine herpesvirus type 1 (ST strain). Virology 199: 409-421.

Lovato TL, Weiblen R, Tobias FL, Moraes MP 1995. Herpesvírus Bovino tipo 1 (HVB1): inquérito soroepidemiológico no rebanho leiteiro do estado do Rio Grande do Sul, Brasil. Ciência Rural 25: 425-430, 1995.

Vidor T, Halfen DC, Riet-Corrêa F, Ribeiro CLG, Schild AL, Raffi MB 1995. Herpes virus bovino tipo 1 (BHV-1): I. Sorologia de rebanhos com problemas reprodutivos. Ciência Rural 25: 421-424.

Payne D, Hoskins S, Schouten H, van Vleuten H, Tyring SJ 1995. Increased buffer $\mathrm{pH}$ enhances sensitivity and specificity of human papillomavirus detection using consensus primer based PCR. Virol Methods 52: 105-110.

TABLE

Primers position, open reading frames and size of amplified product

\begin{tabular}{lccc}
\hline Primers & Position & Orfs US & Product amplified \\
\hline LVC 10/11 & $5^{\prime} 430-417 / 885-8683^{\prime}$ & ORF 1 & $456 \mathrm{bp}$ \\
LVC 12/13 & $5^{\prime} 1159-1177 / 1444-14263^{\prime}$ & ORF 2 & $267 \mathrm{bp}$ \\
LCV 14/15 & $5^{\prime} 2397-2405 / 2682-27003^{\prime}$ & ORF 3 & $303 \mathrm{bp}$ \\
LVC 16/17 & $5^{\prime} 3272-3289 / 3682-36553^{\prime}$ & ORF 4 & $411 \mathrm{bp}$ \\
LVC 18/19 & $5^{\prime}$ 7578-7596/7912-7930 3' & ORF 7 & $352 \mathrm{bp}$ \\
\hline
\end{tabular}

